Zabytkoznawstwo i Konserwatorstwo XLIII, Toruń 2012

Teresa Łękawa-Wysłouch, Bogumiła J. Rouba

Zakład Konserwacji Malarstwa i Rzeźby Polichromowanej

Instytut Zabytkoznawstwa i Konserwatorstwa,

Uniwersytet Mikołaja Kopernika w Toruń

\title{
Ocena wpływu \\ zmiennych warunków klimatycznych na płócienne podłoża malarskie
}

\section{Wstęp}

$\mathrm{O}$ brazy na podłożu płóciennym stanowią niejednorodna, wielowarstwową kompozycję, gdzie różne składniki - bardziej i mniej higroskopijne - reaguja w, nierzadko, odmienny sposób na docierające do nich bodźce zewnętrzne, powodując naprężenia w wewnętrznej strukturze malowideł [1-10]. Jeszcze trudniejsza bywa sytuacja obrazów poddanych w przeszłości zabiegom konserwatorskim, w wyniku których wprowadzono w strukturę nowe, zazwyczaj obce materiały i tworzywa. Rezultatem, trwającej niekiedy wiele lat, zróżnicowanej pracy poszczególnych składników struktury malarskiej, narażonej na przebywanie w niewłaściwych warunkach otoczenia, sa prawie zawsze zmiany i uszkodzenia w postaci poszerzających się z czasem mikrospękań, deformacji, a nawet oddzielania i osypywania się warstw z podobrazia. Droga do zrozumienia zachowania całej tej złożonej struktury jest poznanie zarówno właściwości poszczególnych warstw, jak i sposobu ich reagowania na oddziaływanie zmiennego klimatu w otoczeniu. Celem prowadzonych badań jest poszerzenie wiedzy z zakresu zagadnień związanych z kondycją i stanem zachowania malowideł na płótnie. 
Pytanie o przyczyny zróżnicowanych reakcji obrazów na wahania klimatyczne, przełożono na szereg testów pozwalających zrozumieć czy i w jakim stopniu budowa techniczna obrazu i właściwości materiałów oraz ewentualne błędy technologiczne zaistniałe w procesie twórczym, a także późniejsze ingerencje konserwatorskie mają wpływ na inicjowanie naprężeń i powstawanie zmian w strukturze zabytkowej a tym samym przyspieszanie starzenia. Istotnym problemem badawczym jest określenie wzajemnych relacji najbardziej higroskopijnych składników złożonej struktury malarskiej - płótna i kleju - oraz próba rozstrzygnięcia na ile problem leży w podłożu (płótno i przeklejenie), które uznawane jest za główny czynnik wywołujący naprężenia w obrazach, a w jakim stopniu odpowiedzialność za sposób reagowania na niestabilne warunki leży po stronie samego przeklejenia. I wreszcie - jaki sposób przygotowania podłoża jest najwłaściwszy pod względem zapewnienia stabilności obrazom.

Zagadnienia te, mimo że towarzyszą konserwatorom od kilku dziesiątków lat, nie zostały ostatecznie rozstrzygnięte. Diagnozując przyczyny na podstawie analizy zniszczeń, jak również określając ogólną kondycję obrazów na płótnie, badacze generalnie stwierdzali zmiany wymiarów badanego materiału oraz występowanie naprężeń w poszczególnych warstwach struktury zabytkowej. Chęć poznania genezy tych zjawisk stała się podstawa prac naukowców z niezależnych ośrodków europejskich i światowych na przestrzeni ostatnich czterdziestu lat, począwszy od F. du Pont Corneliusa [11] - który już w 1967 roku zwrócił uwagę na zależność reakcji płótna od kierunku w którym próbkę wycięto - poprzez Volkera Schaible [12], Stephena Hackneya i Gerry'ego Hedleya [13], Debrę Daly i Stefana Michalskiego [14], po Bogumiłę J. Rouba ze współpracownikami [4-7], Marion F. Mecklenburga [9-10, 15-16], Gustawa Bergera i Williama H. Russella [1-3, 17-22], jak również Christinę Young [23-33]. Niektórzy z wymienionych badaczy nadal pozostaja w obszarze zainteresowania tą tematyka. Prowadzone badania koncentrowały się przeważnie na pomiarach naprężeń i odkształceń wywoływanych w strukturze spreparowanych modeli imitujących malowidła na płótnach, a stosowana do tego celu aparatura pomiarowa o różnorodnym charakterze i właściwościach zwykle była autorsko projektowana przez samych badaczy. Skonstruowany, w oparciu o zasadę działania termohigrometru włosowego, przez Schaible instrument umożliwiał 
analizę pojedynczych ruchów płótna, a także monitorowanie odkształceń płótna obciążanego stała siła, poddanego działaniu zmiennych warunków klimatycznych. Nieco inne rozwiązanie zastosowali na potrzeby swoich dociekań Berger i Russell, którzy specjalnie do badań malarstwa sztalugowego na płótnie skonstruowali pierwszy tester naprężeń - „Berger/Russell stress tester”- umożliwiający rejestrację zmian całkowitej długości próbki z duża dokładnościa, przy jednoczesnym pomiarze naprężenia w tkaninie. Co istotne - instrument pozwalał na utrzymanie modelu w stanie naprężenia odpowiadającego realnym wartościom, uzyskiwanym przez obrazy na krosnach malarskich $[18,20,22]$. W obu przypadkach do badań posłużyły odpowiednio przygotowane modele badawcze o zróżnicowanej ilości warstw. Natomiast perspektywę odniesienia wyników badań także do realnej kondycji obrazów zabytkowych otworzyła przed Hackney'em i Hedley’em [13] sposobność wykorzystania naturalnie starzonych płócien i pojedynczych włókien z obrazów z Tate Gallery do prowadzonych przez nich m.in. pomiarów wytrzymałościowych. Pozwoliło to na zweryfikowanie oceny wytrzymałości obiektów przechowywanych w warunkach muzealnych. Nowe możliwości i narzędzia do bezpośredniego badania obiektów zabytkowych zaoferował wkrótce rozwój optycznych technik laserowych, pozwalających na prowadzenie badań w sposób nieinwazyjny. Tego rodzaju badania zaczęła prowadzić Christina Young. Koncentruje się ona na zastosowaniach elektronicznej interferometrii plamkowej (ESPI - ang. Electronic Specle Pattern 2D Interferometry) - która pozwala na uzyskanie trójwymiarowej mapy, po cyfrowym przetworzeniu, uprzednio zarejestrowanych danych - połączonej z dwuosiowym testerem naprężenia $[23,26,31]$. Korzystając z wynalezionego przez Bergera i Russella instrumentu - i potwierdzając zarazem jego przydatność - zastosowała za pomoca ESPI równoczesny pomiar modeli badawczych, o nadanym stałym naprężeniu, zamykając aparaturę badawcza w komorze klimatycznej z regulowanymi warunkami. Young zastosowała ESPI do badania miejsc o szczególnej budowie lub uszkodzeniach, reperacji lokalnych płótna, spękań warstwy malarskiej i zaprawy, efektem czego było zaproponowanie nowatorskich rozwiązań konserwatorskich [28-30, 32]. Ostatnio również (we współpracy z Debashis) rozwinęła swe badawcze zainteresowania w stronę interferometrii 3D, umożliwiającej jednoczesne wielowymiarowe badania [33]. 
Na obecnym etapie rozwoju badań wydaje się, że nowe możliwości w zakresie badania obiektów tekstylnych stoja przed metoda zaczerpnięta z inżynierii materiałowej, jaką jest Cyfrowa Korelacja Obrazów (ang. 3D Digital Image Correlation - 3D DIC) [34]. Znalazła ona już bowiem zastosowanie do bezinwazyjnego, trójwymiarowego badania naprężeń w tkaninach, jak również do długoterminowego monitorowania, powstających na skutek zmian klimatu w otoczeniu, deformacji w historycznych gobelinach [35-36]. Przydatność DIC do badania obrazów na płótnie została ostatnio udowodniona w oparciu o eksperymenty z użyciem specjalnie przygotowanych modeli obrazów, w których imitowano różnorodne reperacje w obrębie warstw pierwotnych. Dzięki metodzie można nie tylko wykryć deformacje i zlokalizować je, ale też określić ich zakres, kształt, a także przebieg w czasie [37]. Poprawienie parametrów urządzenia może wpłynąć znacząco na dalsze wyniki, a także umożliwić badanie rzeczywistych obiektów zabytkowych na płótnie.

Spośród obecnie stosowanych metod na uwage zasługuja ponadto techniki holograficzne: holografia - rejestrująca i odtwarzająca trójwymiarowe obrazy przedmiotów - i interferometria holograficzna - pozwalająca uzyskać odwzorowanie zmian zachodzących w trójwymiarowym obiekcie, dzięki interferencji dwu obrazów uzyskanych przed i po deformacji. Interferometria holograficzna jest wielowariantową metodą stosowana głównie do diagnostyki, monitorowania i dokumentowania stanu obiektów na sztywnych podłożach (malarstwo ścienne, tablicowe, rzeźby). Jest jednak stosunkowo rzadko wykorzystywana ze względu na czasochłonność, kosztowność i wysokie wymagania co do stabilności aparatury [38-41]. Szybszą i prostszą w obsłudze jest, zwana też videoholografia, wzmiankowana już elektroniczna interferometria plamkowa ESPI. Opisy tych metod, z głównym zastosowaniem do badań obiektów na sztywnych podłożach, zawieraja przeglądowe artykuły autorstwa Dulieu-Bartona i in. [38], a także Ambrosini'ego i Paoletti [39].

Odnotować należy też dwa innego rodzaju narzędzia przydatne do monitorowania naprężeń i odkształceń tekstyliów. Pierwszym z tych narzędzi są włókna optyczne wykorzystywane jako czujniki do pomiaru naprężeń, wykrywania deformacji i uszkodzeń materiałów. Krzemionkowe włókna optyczne, w których czułym elementem jest światłowodowa siatka 
Bragga (FBG - ang. Fibre Bragg Grating) zastosowane zostały do monitorowania zabytkowych tkanin w ekspozycji muzealnej: wełniano-lnianego kilimu (gdzie len stanowił osnowę a wełna wątek) i wełnianego gobelinu flamandzkiego [42]. Pomiary wykazały, że tkaniny odpowiadaja prawie natychmiast na wahania wilgotności względnej, przy czym znacznie silniej w kierunku wątku.

Drugie narzędzie o charakterze kontaktowym wykorzystuje czujniki tensometryczne do badania zmian liniowych odkształceń obiektów. Przed kilkunastu laty w Toruniu podjęto próby wykorzystania tensometrii elektrooporowej do monitorowania naprężeń w płóciennych podobraziach malarskich $^{1}[43,44]$. Tensometria oporowa, stosując czujniki tensometryczne, powoduje miejscowe usztywnienie badanego materiału, co wykazały równoczesne badania $z$ wykorzystaniem ESPI prowadzone przez Young [23]. Badania prowadzone za pomocą obydwu tych metod należą, w odróżnieniu od wyżej wzmiankowanych metod optycznych, do grupy metod kontaktowych - co jest ich zasadniczą wada. Ponadto czujniki stosowane do badań należy specjalnie dostrajać do właściwości badanego obiektu a wyniki badań są bardzo trudne do opracowania i interpretacji.

Dynamiczny rozwój metody Tomografii Optycznej (OCT), która oprócz podstawowych zastosowań medycznych znalazła wykorzystanie do badania przedmiotów zabytkowych, zrodził nadzieje na możliwość rozwiązania także i zagadnień związanych $\mathrm{z}$ reakcjami obrazów płóciennych na zmienne warunki klimatyczne przy użyciu tej właśnie metody. Obok głównego nurtu zastosowań do badania wewnętrznej struktury, dzięki przezroczystości warstw dla promieniowania podczerwonego, OCT bowiem daje też możliwość wykorzystania jako narzędzie profilometryczne, umożliwiające precyzyjne śledzenie deformacji badanej powierzchni w trzech kierunkach jednocześnie, co zostało potwierdzone we wcześniejszych badaniach toruńskiego zespołu [45-48].

1 Badania nad tym trudnym tematem prowadzone były między innymi $\mathrm{w}$ ramach prac magisterskich w ZKMiRP. Nowatorska pod tym względem była praca A. Guzowskiej z 1996 roku. Do badań została wówczas specjalnie zaprojektowana i wykonana w Instytucie Fizyki aparatura, która umożliwiła obserwację mikroruchów płócien i pomiar wywoływanych w nich naprężen. W ostatnich latach temat został powtórnie podjęty we współpracy z UKW w Bydgoszczy i zrealizowany w ramach pracy M. Gurby. 


\section{Tomografia optyczna (OCT)}

Podstawowym narzędziem badawczym, które wykorzystano w przeprowadzonych badaniach jest Spektralny Tomograf OCT, opracowany i zmodernizowany specjalnie dla badań konserwatorskich w Zespole Fizyki Medycznej IF WFiA UMK.

Tomografia Optyczna (ang. Optical Coherence Tomography, OCT) - tomografia z zastosowaniem interferometrii światła częściowo spójnego - jest nowoczesną, dynamicznie rozwijająca się technika, która umożliwia badanie wewnętrznej struktury przedmiotów, których warstwy sa przynajmniej częściowo przezroczyste. Technika ta pozwala uzyskiwać obrazy przekrojów badanych obiektów. Dzieje się tak na skutek wydobycia informacji dostarczanej przez światło rozproszone w kierunku wstecznym na nieciagłościach struktury tego obiektu. W metodzie stosuje się promieniowanie podczerwone o mocy zaledwie kilku miliwatów (do 1,5 $\mathrm{mW}$ ) na obiekcie, co decyduje o jej nieinwazyjnym charakterze. Podkreślić należy, iż jest to metoda szybka, całkowicie bezkontaktowa, co zapewnia bezpieczeństwo zabytkowej strukturze, może być zatem stosowana kilkakrotnie i powtarzana w wielu miejscach obiektu bez ryzyka spowodowania uszkodzeń. W czasie przeprowadzania eksperymentu $\mathrm{w}$ najmniejszym nawet zakresie nie zmienia właściwości badanego obiektu, nie wprowadza naprężeń i nie wpływa tym samym na zafałszowanie wyników pomiarów.

Specyficznym, nietypowym sposobem wykorzystania urządzenia OCT jest zastosowanie go jako narzędzia profilometrycznego, gdzie podczas badań nie jest wymagana nawet częściowa przejrzystość warstw badanego obiektu. W szczególnym przypadku możliwe jest wykrywanie i rejestrowanie położenia punktu na powierzchni badanego przedmiotu oraz jego przesunięcia w trzech kierunkach jednocześnie, a więc nie w płaszczyźnie, ale w przestrzeni, co należy uznać za najistotniejszą zaletę metody, wyróżniająca ją pozytywnie na tle innych rozwiazań - metody fazowe, takie jak interferometria plamkowa czy holografia, mimo że bardziej czułe odznaczają się trudnością $\mathrm{w}$ równoczesnym pomiarze przemieszczania w płaszczyźnie powierzchni obiektu i w kierunku prostopadłym do tej powierzchni. Ponadto zaletą tech- 
niki OCT jako metody natężeniowej, jest to, że nie korzysta ona z informacji fazowej. Wyznaczenie położenia obiektu przed i po zmianie warunków środowiska odbywa się niezależnie. Specyfika dwukrotnego pomiaru - przed i po zadziałaniu czynnika z otoczenia - niezbędnego do uzyskania informacji o fazie fali świetlnej rozproszonej na obiekcie, z porównania których wyznacza się przesunięcie - sprawia, że obiekt wymaga stabilizacji względem układu pomiarowego z dokładnością do ułamka długości fali. W rzeczywistości oznacza to konieczność umieszczenia obiektu z detektorem na stole optycznym w laboratorium. Na pomiar metodą OCT nie mają wpływu zmiany wartości współczynnika załamania światła w powietrzu wokół badanego obiektu wywołane zmianami temperatury otoczenia, podczas gdy w przypadku wyznaczania fazy fali rozproszonej wpływ ten jest znaczacy. OCT jest także pozbawiona niejednoznaczności wyznaczenia położenia charakterystycznego dla metod fazowych (phase ambiguity), jak błąd kierunku i błąd periodyczności. Tak więc badanie może być wykonane wszędzie i w każdych warunkach, podczas gdy w przypadku pozostałych metod występuje znaczna trudność w przeniesieniu pomiarów do autentycznego środowiska obiektu. Niegodnością metody OCT jest względnie niewielki obszar możliwy do równoczesnego badania - zazwyczaj nie przekracza on rozmiarów $15 \times 15 \mathrm{~mm}$.

Wszystkie urządzenia OCT wyposażone są w specyficzne źródła promieniowania podczerwonego, zapewniające - dzięki dużej spójności przestrzennej - uzyskanie znacznej czułości tomografu. Druga właściwość charakteryzująca źródło promieniowania - mała spójność czasowa (wynikająca z dużej szerokości spektralnej widma promieniowania) - określa inny ważny parametr urządzenia, jakim jest osiowa zdolność rozdzielcza (w głąb badanego obiektu). Wielkość ta pozwala oszacować minimalną, możliwą do zarejestrowania, grubość obserwowanej warstwy. W urządzeniu skonstruowanym dla potrzeb badań konserwatorskich w Instytucie Fizyki UMK jako źródło światła zastosowano zespół sprzężonych optycznie diod superluminescencyjnych emitujący światło podczerwone o zakresie długości fal od $790 \mathrm{~nm}$ do $900 \mathrm{~nm}$ o bezpiecznym natężeniu 0,6-1,5 mW. Rozdzielczość osiowa w toruńskim tomografie wynosi 4,0 $\mu \mathrm{m}$ w powietrzu, natomiast rozdzielczość poprzeczna, która determinuje minimalny rozmiar obserwowanych struktur wynosi ok. $30 \mu \mathrm{m}$. Szczegóły budowy tomografu można znaleźć w artykule [49]. 
Konstrukcje i właściwości wszelkich odmian OCT są szczegółowo opisane w literaturze przedmiotu (obszerne omówienie prezentuje np. monografia pod redakcją Fujimoto [50], natomiast przegląd zastosowań do badań materiałowych znajdziemy w artykule Stiftera [51]. Zastosowania ściśle konserwatorskie omówione są w dwu artykułach przeglądowych [45, 52]. Zestawienie wszystkich dotąd opublikowanych w jezzyku angielskim i polskim na świecie doniesień dotyczących wykorzystania tomografii optycznej do badań dzieł sztuki i w ich konserwacji zawiera witryna internetowa www. oct4art.eu.

\section{Metodyka badań}

Badania wykonane zostały na modelach symulujących obrazy na podłożach płóciennych o różnorodnych strukturach:

- na nowym fabrycznym płótnie o charakterze zbliżonym do regularnego,

- na nowym fabrycznym płótnie o nieregularnym charakterze,

- na kilku różnych starych płótnach, uzyskanych po rozdublowaniu wtórnego wzmocnienia podłoża obrazów zabytkowych dodatkowym płótnem.

Płótna przeklejono jednym rodzajem kleju (żelatyna techniczna) w dwu różnych stężeniach i dwu postaciach:

- 5\% i $15 \%$ zimnymi zżelowanymi oraz

- 5\% i $15 \%$ ciepłymi płynnymi roztworami.

$\mathrm{Na}$ wszystkie tak przygotowane podłoża naniesiono dwukrotnie biała zaprawę emulsyjną i monochromatyczne warstwy malarskie, składające się z trzech warstw ugrowej tempery kazeinowej i wykończeniowego alizarynowego olejnego laserunku. Jedną partię modeli badawczych pozostawiono bez wprowadzania dodatkowych substancji, w stanie czystym technologicznie, dwie pozostałe grupy przesycono spoiwami konsolidującymi o zróżnicowanym charakterze:

— wodnym - 7\% polialkoholem winylowym (druga grupa),

- rozpuszczalnikowym - 20\% roztworem BEVA 371 w benzynie lakowej (trzecia grupa). 
Próbki przygotowywano w sposób analogiczny do technologii wykonywania dawnych malowideł - poszczególne warstwy nakładane były na zdekatyzowane i pozbawione zanieczyszczeń płótna naprężone i przymocowane zszywkami tapicerskimi do drewnianych krosien malarskich. W takiej postaci próbki sezonowano kilkanaście miesięcy w warunkach powietrzno-suchych (temp. 19-22 C, RH 35-55\%). W celu wyeliminowania wpływu higroskopijnego drewna na reakcje płócien i uniknięcia zafałszowania wyników pomiarów, przed przystapieniem do etapu badań zrezygnowano z tradycyjnych blejtramów na rzecz metalowego krosna, obojętnego wobec wahań klimatycznych. Z przygotowanych modeli wycięto próbki o wymiarach $11,0 \times 11,0 \mathrm{~cm}$ i kolejno montowano w szczękach metalowych krosien, z których dwie były nieruchome, dwie zaś na przegubach umożliwiających swobodny ruch płótna, połączone $z$ tensometrami. Zaopatrzenie w sprężynę śrub dociskowych służących do regulacji naprężenia próbki zapewniało utrzymanie stałego poziomu naprężenia, który wyjściowo ustalono na ok. $13 \mathrm{~N}(+/-0,5 \mathrm{~N})^{2}$ (il. 1$)$.

Tak przygotowany układ badawczy pozostawał w komorze klimatycznej przez ok. $12 \mathrm{~h}$, co pozwalało na relaksację, ustabilizowanie i ustalenie się właściwego - dla konkretnej próbki - naprężenia początkowego. Uzależnione ono było od sztywności/elastyczności próbki oraz poziomu wilgotności względnej w otoczeniu. Zwykle po upływie tego czasu naprężenie nieznacznie spadało, w przypadku kilku próbek nieco wzrosło. Przed przystapieniem do pomiarów nie regulowano już naprężenia, do którego samoczynnie ustawiła się próbka, traktując je jako specyficzne i charakterystyczne dla danego modelu. Układ badawczy skonstruowany został z dwu komór - głównej większej, szczelnej, wykonanej ze szkła, pleksiglasu i aluminium, ustawionej na stole optycznym - w niej umieszczano

2 Wartość określono na podstawie wyników badań G. A. Bergera i W. H. Russella [18], którzy ustalili, że wartości siły, z jaką można naprężyć płótno nie powodując jego widocznego odkształcenia plastycznego jest niska i zawiera się miedzy 60 a 130 N/m. Jeśli płótno zostanie naprężone na stałym krośnie powyżej tej granicy dochodzi do jego plastycznego odkształcenia, a naprężenie gwałtownie spada do wartości maksymalnego utrzymywanego naprężenia (MST), którą tkanina jest w stanie utrzymać. MST wyraża górny próg dopuszczalnej wartości naprężeń w obrazach na płótnie i jest znacznie niższy niż wartości zwykle stosowane w przemyśle do badania nośności lub siły tkaniny. 
metalowe krosno z naprężona próbką wsparte na czterech stalowych podporach. Mniejsza komora z tworzywa sztucznego, która stanowiła magazyn wilgoci bądź substancji osuszającej - żelu silikonowego (w zależności od rodzaju cyklu) usytuowana była poza stołem i połączona z komora główną elastycznymi rurami transportującymi wilgoć (il. 2). Sprawny transport wilgoci zapewniało zastosowanie elektrycznego wentylatora o niskim napięciu (12 V), zlokalizowanego w miejscu połączenia jednej z rur ze ścianką mniejszej komory. Każda próbka poddawana była kontrolowanemu oddziaływaniu klimatu o zmiennej wilgotności względnej i stałej temperaturze $\mathrm{w}$ dwukrotnie powtarzanych, czterogodzinnych cyklach nawilżania (40-60-90-60-30-40\% Rh), oraz w, trwających także cztery godziny, dwóch cyklach przesuszania (50-20-50\% Rh), których przebieg zaprojektowano w oparciu o wyniki badań klimatycznych w warunkach rzeczywistych (w zabytkowych kościołach, a także w pomieszczeniach muzealnych) ${ }^{3}$. Podczas trwania każdego cyklu obserwowano i - przy użyciu komputera - rejestrowano położenie punktu znajdującego się na powierzchni warstwy malarskiej, jednocześnie w trzech kierunkach: X, Y (osnowy i wątku) oraz w kierunku Z (w kierunku prostopadłym do płaszczyzny). Punkt pomiarowy został wyznaczony w narożniku próbek znajdującym się najbliżej tensometrów, w odległości 2,0 $\mathrm{cm} \times 2,0 \mathrm{~cm}$ od krawędzi lica, a stanowiła go maleńka kropka naniesiona koniuszkiem srebrzystego markera na czarny podkład w formie kwadratu o boku $1,0 \mathrm{~cm}$, wykonany farbą wodną ${ }^{4}$. Równocześnie drugi komputer rejestrował wartości naprężeń w kierunku wątku i osnowy próbek, a także wartości wilgotności względnej i temperatury wewnątrz komory głównej - te dwa ostatnie parametry przy użyciu czujnika HygroClip ${ }^{\circledR}$ S firmy Rotronic (Switzerland).

3 Badania te prowadzone są od wielu lat przez B. J. Roubę i L. Tymińską-Widmer z ZKMiRP. Autorki analizując pomiary klimatyczne zauważyły, że tempo zmian, uwarunkowane użytkowaniem typowym dla miejsc kultu religijnego i ośrodków kultury, jest dużo większe niż przeciętnie spotykane. Wyniki tych badań posłużyły do zaprojektowania przebiegu zmian wilgotności względnej w opisywanych badaniach

${ }_{4}^{4}$ Stanowiła go czerń kostna sklejona 2,5\% PAW. Zastosowanie całkowicie matowego podkładu wokół błyszczącego znacznika okazało się koniecznością ze względu na niewielką możliwość przechwycenia przez układ optyczny konkurencyjnego refleksu, pochodzącego z nierówności połyskliwej warstwy malarskiej i tym samym zafałszowanie pomiarów. 


\section{Rezultaty badań}

Wyniki uzyskano w postaci danych liczbowych, rejestrowanych co 120 sekund (położenie współrzędnych monitorowanego punktu) na jednym i co 10 sekund (wilgotność względna, temperatura, naprężenia) na drugim komputerze. Wykorzystano je do wstępnego graficznego przedstawienia przebiegu eksperymentów. $\mathrm{Na}$ wspólnym dla pojedynczego cyklu wykresie zobrazowano liniowo najważniejsze parametry, to jest: odkształcenia współrzędnych X, Y, Z obserwowanego punktu, zmiany wilgotności względnej powietrza, a także wartości naprężeń w kierunku F1(y) i F2(x) badanej próbki. Przykładowe wykresy prezentowane poniżej zestawione sa dla modeli na różnych płótnach: regularnym, nieregularnym i starym, przeklejonych takim samym klejem - 15\% żelatyna techniczną zaaplikowana na ciepło, bez dodatkowych spoiw konsolidujących. Wszystkie trzy wykresy ukazuja przebieg pierwszych cykli, w trakcie których próbki poddano gwałtownemu nawilżaniu zakończonemu stabilizacją warunków (il. 3), a kilka tygodni później przesuszaniu poniżej poziomu zalecanego dla przechowywania zabytków (il. 4). Zestawienie pozwala dostrzec różnice w zakresie i przebiegu odkształceń współrzędnych X, Y, Z pomiędzy poszczególnymi płótnami. W każdym z trzech kierunków odkształcenie jest wyraźne, najmocniejsze w kierunki $\mathrm{Y}$ zgodnym $\mathrm{z}$ wątkiem - w trakcie nawilżania nastapiła natychmiastowa wielokierunkowa reakcja próbki na wzrost wilgotności względnej w jej otoczeniu, a także zmiana wymiarów próbek spowodowana najprawdopodobniej pęcznieniem kleju, który zdominował płótno. Po zakończeniu nawilżania odkształcenia nieco złagodniały i cofnęły się, ale nie powróciły do położenia wyjściowego nawet po ustabilizowaniu się warunków. W przypadku cykli przesuszania na płótnie regularnym największe odkształcenie miało miejsce $\mathrm{w}$ kierunku $Z$, przy prawie jednakowo reagujących X i Y. Na wykresie środkowym, który dotyczy nieregularnego płótna, na spadek wilgotności najmocniej zareagował kierunek X zgodny z osnowa, w płótnie starym odpowiedź we wszystkich kierunkach była zbliżona i stosunkowo niewielka, a odkształcenie niemal powróciło do początkowego położenia. Taka forma zobrazowania wyników, przy tak dużej 
ilości materiału porównawczego może być traktowana jedynie jako wstępna. Jednak już takie porównanie wykresów pozwoliło zauważyć różnice w reakcjach poszczególnych próbek na wahania klimatyczne:

- w obrębie takich samych płócien (w każdej z trzech grup) przy zróżnicowanym przeklejeniu - zarówno pod względem stężenia (5\%, 15\%), jak i postaci kleju (zimny, ciepły),

— pomiędzy różnymi rodzajami płótna,

- pomiędzy płótnami czystymi, niekonsolidowanymi a płótnami z wprowadzonym spoiwem konsolidującym - a także pomiędzy płótnami z różnymi konsolidantami.

W celu bardziej precyzyjnego wychwycenia tych różnic, w następnym etapie opracowywania wyników badań sporządzono wykresy, gdzie w trzech grupach odpowiadających zróżnicowaniu techniki modeli badawczych zestawiono odkształcenia poszczególnych współrzędnych dla różnych próbek (oddzielnie dla X, Y i Z) na tle warunków klimatycznych (il. 5). Zestawienia wykonano dla:

I. Jednakowych płócien z różnymi przeklejeniami (cztery próbki na jednym wykresie):

- płótno regularne z przeklejeniem 5 i 15\% aplikowanym na zimno i 5 i $15 \%$ aplikowanym na ciepło,

- płótno nieregularne z przeklejeniem 5 i 15\% aplikowanym na zimno i 5 i $15 \%$ aplikowanym na ciepło,

- płótna stare z przeklejeniem 5 i 15\% aplikowanym na zimno i 5 i 15\% aplikowanym na ciepło,

(wszystkie trzy grupy z wyodrębnieniem próbek bez spoiwa konsolidującego i z dwoma różnymi spoiwami konsolidującymi, co dało trzy podgrupy w każdej grupie - łącznie 12).

II. Jednakowych przeklejeń na różnych płótnach (trzy próbki na jednym wykresie):

- płótna regularne, nieregularne i stare z przeklejeniem 5\% aplikowanym na zimno,

- płótna regularne, nieregularne i stare z przeklejeniem 15\% aplikowanym na zimno,

- płótna regularne, nieregularne i stare z przeklejeniem 5\% aplikowanym na ciepło, 
- płótna regularne, nieregularne i stare z przeklejeniem 15\% aplikowanym na ciepło,

(wszystkie cztery grupy z wyodrębnieniem próbek bez spoiwa konsolidujacego i z dwoma różnymi spoiwami konsolidującymi, co dało trzy podgrupy w każdej grupie - łącznie 12).

III. Jednakowych płócien z takim samym przeklejeniem bez spoiwa konsolidującego i z dwoma różnymi spoiwami konsolidującymi (trzy próbki na jednym wykresie):

- jednakowe przeklejenia 5\% aplikowane na zimno na identyczne płótna $\mathrm{w}$ trzech wariantach przesycenia - bez konsolidacji, z 7\% PAW i z 20\% BEVA 371,

- jednakowe przeklejenia 15\% aplikowane na zimno na identyczne płótna w trzech wariantach przesycenia - bez konsolidacji, z 7\% PAW i z 20\% BEVA 371,

- jednakowe przeklejenia 5\% aplikowane na ciepło na identyczne płótna w trzech wariantach przesycenia - bez konsolidacji, z 7\% PAW i z 20\% BEVA 371,

- jednakowe przeklejenia 15\% aplikowane na ciepło na identyczne płótna w trzech wariantach przesycenia - bez konsolidacji, z 7\% PAW i z $20 \%$ BEVA 371 ,

(wszystkie cztery grupy z wyodrębnieniem próbek na płótnach regularnych, nieregularnych i starych, co dało trzy podgrupy w każdej grupie - łącznie 12).

Biorąc pod uwagę fakt czterokrotnego badania każdej próbki - a więc dużą ilość przeprowadzonych eksperymentów, liczebność wariantów zestawień krzywych odkształceń współrzędnych X, Y, Z uzyskano kilkaset wykresów, które, co prawda pokazuja odmienne reakcje poszczególnych próbek $\mathrm{i}$ ich jednostkowe relacje, ale $\mathrm{z}$ racji ilości utrudniaja wyciaganie wniosków. Dodatkowo sytuację komplikuje fakt, że tło klimatyczne badań ustawiane było ręcznie $\mathrm{i} \mathrm{w}$ pewnym stopniu uzależnione od zmiennych warunków, panujących w laboratorium ${ }^{5}$. W efekcie, w przebiegu nawilżania i osuszania w obrębie poszczególnych eksperymentów dały się zauważyć pewne, $z$ reguły nieznaczne odchylenia, od zaprojektowanego wzorcowego

\footnotetext{
5 Badania podzielone były na kilka etapów, zbiegających się w czasie $\mathrm{z}$ różnymi porami roku i towarzyszącym im sezonem grzewczym lub jego brakiem
} 
cyklu. Dlatego proste porównywanie wykreślonych krzywych odkształceń, w oderwaniu od tła klimatycznego - lub zastosowanie wzorcowego, który nie był prawdziwy dla wszystkich przypadków - obarczone byłoby błędem.

Dla dalszej analizy wyników, biorąc pod uwagę wielką ilość zgromadzonych danych, zdecydowano dokonać wyboru poprzez wyznaczenie kilku prostych wskaźników numerycznych, które umożliwiłyby uszeregowanie wyników badań i analizę pod kątem zależności reakcji próbek od różnych czynników ${ }^{6}$. Dla wszystkich współrzędnych wyznaczono kilka parametrów: - maksima i minima dla odkształceń współrzędnych X, Y, Z wszystkich próbek w każdym pojedynczym cyklu;

- obliczono amplitudy - różnice między wartością maksymalna, a wartością minimalną odkształcenia współrzędnych X, Y, Z $\left(\Delta_{\mathrm{X}}, \Delta_{\mathrm{Y}} \Delta_{\mathrm{Z}}\right)$ wszystkich próbek we wszystkich cyklach w wybranych zakresach wilgotności względnej, tj.: 45-23\%, 50-65\%, 50-70\%, 70-88\%, uwzględniając przy tym fazy wzrostu i spadku wilgotności względnej;

- obliczono wartość przesunięcia badanego punktu w przestrzeni (długość wektora translacji W) między położeniem początkowym a końcowym, w wybranych zakresach wilgotności względnej (jak wyżej podane):

$$
w=\sqrt{w_{X}^{2}+w_{Y}^{2}+w_{Z}^{2}} ;
$$

gdzie $w_{X}-$ przesunięcie w kierunku współrzędnej X punktu, $w_{Y}-$ przesunięcie w kierunku współrzędnej Y punktu, $w_{Z}-$ przesunięcie w kierunku współrzędnej $Z$ punktu.

Wartości amplitud $(\Delta)$ i translacji obliczono dla wybranych zakresów wilgotności względnej powietrza, charakteryzujących się 15-20\% skokiem wartości. Posortowanie danych pod względem rosnących lub malejących wartości liczbowych, pozwoliło na uszeregowanie próbek i wychwycenie różnic w reakcjach modeli obrazów na wahania klimatyczne i określenie zależności. Zamieszczone w Aneksie przykładowe tabele, liczbowo wyrażające odkształcenia, prezentują dane posortowane pod względem malejacej wartości translacji dla zakresu $50-70 \%$ oraz $70-88 \%$ RH.

\footnotetext{
6 Program służący do uszeregowania wyników napisał i opracował prof. Piotr Targowski z IF UMK w Toruniu.
} 


\section{Wnioski}

Wyniki badań dowodza, że metoda OCT, mimo że nie jest to jej podstawowe zastosowanie, jest przydatna do śledzenia reakcji obrazów na zmiany klimatu i sprawdza się także jako narzędzie profilometryczne. Jest w stanie wykryć ruch obserwowanego punktu na powierzchni obrazu i śledzić jego przemieszczanie się $\mathrm{w}$ niewielkim polu, nie wywołując zmian w badanym obiekcie. Rozmiar pola obserwacyjnego i punktowy charakter pomiarów sa mankamentem metody. Trudno np. wyjaśnić przyczynę „falującego” odkształcania współrzędnej Z, dysponując tylko wynikami pomiarów w jednym punkcie. Mimo to metoda pozwala, dzięki zebranej w wielogodzinnych sesjach badawczych bazie porównawczej, odczytać różnice i zależności, umożliwiając tym samym dociekanie przyczyn, instrumentalnie stwierdzonych reakcji. Analiza uzyskanych wyników pokazuje zależność sposobu reagowania obrazów na zmienne warunki klimatyczne i wrażliwość na nie od ich budowy technicznej. Już niewielkie wahnięcie poziomu wilgotności względnej w zakresie między 50 a $\mathbf{6 5 \%}$ wywołuje reakcje modeli badawczych - w przeważającej większości intensywniejszą tam, gdzie płótno przeklejone jest silnym 15\% klejem - przede wszystkim aplikowanym na ciepło, ale także na zimno. W większości przypadków, są to równocześnie próbki nie konsolidowane dodatkowo innym spoiwem. W tej grupie najliczniej występuja płótna stare, które stanowią $2 / 3$ próbek. Płótna regularne i nieregularne nieco mniej intensywnie odpowiadają na bodźce klimatyczne, a ich ilość jest mniejsza o około 1/3. Najmniej reaktywne okazały się próbki przesycone spoiwem konsolidującym - i to zarówno rozpuszczalnikowym, jak i wodnym. W nieco szerszym zakresie wilgotności względnej między 50 a 70\% największa reaktywność wykazuja również próbki bez konsolidantów, najczęściej zarazem z mocnym przeklejeniem (vide: tabela 1). Sytuacja ulega zmianie dopiero w zakresie wilgotności najwyższych - między 70 a 88\%. Najsilniejszą odpowiedź na wzrost wilgotności dają głównie płótna stare, ale także nieregularne wraz z regularnymi - wszystkie przeklejone przeważnie 15\% klejem zakładanym na ciepło, ale również na zimno, które przy niższych wahaniach wilgotności reagowały w sposób 
umiarkowany. Podobną tendencję zauważono analizując reakcje próbek zarejestrowane przy spadku wilgotności względnej w zakresie 45 do $23 \%$ (vide: tabela 2). Także w tym przypadku różnorodne płótna przesycone $15 \%$ żelatyną reagowały szybko i intensywnie na zmianę poziomu wilgotności względnej w otoczeniu

Wyniki te potwierdzają większa, niż się powszechnie sądzi, rolę przeklejenia w strukturze obrazu na płótnie. Ciekawa jest zaobserwowana tendencja do opóźniania reakcji w modelach dodatkowo przesyconych spoiwami konsolidującymi. O ile w wyniku użycia rozpuszczalnikowego preparatu BEVA 371 zmniejszenie higroskopijności całego układu jest dość oczywiste, o tyle wodny polialkohol winylowy jako spoiwo higroskopijne, jak się wydaje powinien jeszcze dodatkowo tę pracę wzmacniać. Interpretując ten fakt można przyjąć, że przesycenie tym spoiwem, które jest wprawdzie higroskopijne, ale w mniejszym stopniu niż klej glutynowy i płótno powoduje zablokowanie pracy płótna w początkowym okresie skoku wilgotnościowego, a przez to opóźnienie reakcji całego układu i dopiero przy dłuższej ekspozycji na wilgoć zarówno konsolidant, jak i za jego pośrednictwem płótno, intensyfikują pracę.

Zebrany ogromny materiał badawczy został przeanalizowany tylko w niewielkiej części a najważniejsze ustalenia przedstawione w sposób bardzo skrótowy. W najbliższym czasie prowadzona będzie bardziej szczegółowa analiza wyników i dalsza ich interpretacja, także analiza wyników skrajnych, na pierwszy rzut oka wyglądających niejednoznacznie. Pogłębione opracowanie danych, zarówno na podstawie ich prezentacji graficznej, jak i analizy numerycznej, w powiązaniu $z$ analizą samego modelu badawczego da z cała pewnością odpowiedzi na wiele jeszcze szczegółowych kwestii.

\section{Bibliografia}

1. G. A. Berger, W. H. Russell, Badania nad wplywem środowiska na zachowanie obrazón na ptótnie, Restauro, 1983/3, s. 191-203.

2. G. A. Berger, W. H. Russell, Deterioration of surfaces exposed to environmental changes, Journal of the Ammerican Institute for Conservation, 29(1), 1990, s. 45-76, [dokument elektroniczny] tryb dostepu: http://cool.conservation-us.org/jaic/ articles/jaic29-01-004_indx.html 
3. G. A. Berger, W. H. Russell, Interaction between canvas and paint film in response to envirinmental Changes, Studies in Conservation, 39, 1994, s. 73-86.

4. B. J. Rouba, Ptótna jako podobrazia malarskie, Ochrona Zabytków 3-4, 1985, s. $222-244$.

5. B. J. Rouba, Budowa techniczna obrazón XIX-wiecznych malowanych na handlowych podobraziach plóciennych $i$ tematyka ich konserwacji, Wydawnictwo UMK, Torun 1988.

6. B. J. Rouba, Die Leinwandstrukturanalyse und ibre Anwendung für Gemäldekonservierung, Restauratorenblätter 13, s. 79-90 (1992).

7. B. J. Rouba, Podobrazia ptócienne w procesie konserwacji, Wydawnictwo UMK, Toruń 2000.

8. A. Karpowicz, A Study on Development of Cracks on Paintings, Journal of the American Institute for Conservation 29(2), 1990, s. 169-180, [dokument elektroniczny] tryb dostępu: http://aic.stanford.edu/jaic/articles/jaic29-02-2005.html

9. M. F. Mecklenburg, The Structure of Canvas Supported Paintings, Preprints of the International Conference on Painting Conservation - Canvases: Behaviour, Deterioration and Treatment, 2005, s. 119-155.

10. M. F. Mecklenburg, Micro Climates and Moisture Induced Damage to Paintings, Conference on Micro Climates in Museums, 2007, s. 19-25.

11. F. du Pond Cornelius, Movement of Wood and Canvas for Paintings in Response to High and Low RH Cycles, Studies in Conservation, 12, 1967, s. 76-80.

12. V. Schaible, Neue Überlegungen zur Feuchtigkei AM Leinwandbild, Zeitschrift für Kunsttechnologie und Konservierung, 1, 1987, H. 1, s. 75-94.

13. S. Hackney, G. Hedley, Measurement of the Ageing of Linen Canvas, Studies in Conservation, 26, 1981, s. 1-14; G. Hedley, Relative Humidity and Stress/Strain Response of Canvas Paintings: Uniaxial Measurements of Naturally Aged Samples, Studies in Conservation, 33(3), 1988, s. 133-148.

14. D. Daly, S. Michalski, Methodology and status of the Lining Project, CCI, Preprints, ICOM, $8^{\text {th }}$ Triennal Meeting, Sydney, 1987.

15. J. Colville, W. Kilpatrick, M. F. Mecklenburg, Finite Element Analysis of Multi Layered Orthotropic Membranes with Application to Oil Paintings on Fabric, Science and Technology in the Service of Conservation, IIC, London, 1982, s. 46-150.

16. M. F. Mecklenburg, M. McCormick-Goodhart, C. S. Tumosa, Investigation into the Deterioration of Paintings and Photographs using Computerized Modeling of Stress Development, [dokument elektroniczny] tryb dostępu: http://aic.stanford.edu/ jaic/articles/jaic33-02-007.html

17. W. H. Russell, G. A. Berger, The behavior of canvas as a structural support for painting, Science and Technology in the Service of Conservation, IIC-Washington Congress, London: IIC. 1982, 139-45. 
18. G. A. Berger, W. H. Russell, The New stress tests on Canvas Paintings and some of their implications on the preservation of paintings, Preprints ICOM Committee for Conservation 7th Triennial Meeting, Copenhagen 1984, Bd. 2, s. 7-9.

19. G. A. Berger, W. H. Russell, Investigations into the Reactions of Plastic Materials to Environmental Changes. Part I. The Mechanics of the Decay of Paint Films, Studies in Conservation, 31, 1986, s. 49-64.

20. G. A. Berger, W. H. Russell, An Evaluation of the Preparatuin of Canvas Paintings Using Stress Measurements, Studies in Conservation, vol. 33, 4/1988, s. 187-204.

21. G. A. Berger, W. H. Russell, Changes in Resistance of Canvas to Deformation and Cracking (Moduls of Elasticity 'E") as Caused by Sizing and Luning, Preprints ICOM Committee for Conservation, 7th Triennial Meeting, Copenhagen 1990, s. 107-112.

22. G. A. Berger, The Berger-Russell biaxial stress tester for stretcher canvas, [w:] Berger Gustaw A., Russell William H., Conservation of Paintings: Reserch and Innovations, Archetype, London, UK, 2000, s. 265-272.

23. C. Young, Quantitative measurement of in-plane strain of canvas paintings using ESPI, [w:] Applied Optics Division, s. 79-84, Institute of Physics, IOP, Brighton, UK, 1998.

24. C. Young, R. D. Hibberd, A Comparison of the Physical Properties of Nineteenth Century Canvas Linings with Acid Aged Canvas, Preprints ICOM Commitee for Conservation, vol. 1, 1999, s. 353-360.

25. C. Young, R. D. Hibberd, Biaxial Tensile Testing of Paintings on Canvas, Studies in Conservation, 44, 1999, s. 129-141.

26. C. Young, Measurement of the Biaxial Properties of Nineteenth Century Canvas Primings Using Electronic Speckle Pattern Interferometry, Optics and Lasers in Engineering, Special Edition, 31, 2, 1999, s. 163-170.

27. C. Young and R. Hibberd, The role of canvas attachments in the strain distribution and degradation of easel paintings, Tradition and Innovation: Advances in Conservation, Contributions to the IICMelbourne Congress, London, UK, October 2000, s. 212-220.

28. C. Young, R. Hibberd, P. Ackroyd, An investigation into the adhesive bond and transfer of tension in lined canvas paintings, Proceedings of the 13th Triennial Meeting of the ICOM Committee for Conservation (ICOM-CC '02), Rio de Janeiro, Brazil, September 2002, s. 370-378.

29. C. Young, The mechanical requirements of tear mends, Alternatives to lining, BAPCR \& UCIK Conference, 2003, s. 55-58.

30. J. Dimont, C. Young, Reducing Cupping Without Lining, Alternatives to Lining, 2003, s. 29-33. 
31. CRT. Young, M. Debashis, Using ESPI to Characterise the Mechanical Behaviour of Paintings on Canvas, accepted for 12th International User EPSI Group Meeting, Germany Oct., 2005.

32. CRT. Young, Developing Mechanical Tests to Evaluate Consolidation Treatments on Canvas Paintings, 3rd International Congress Colore e Conservazione Proceedings, Il Prato, Italy 2008, s. 71-78.

33. M. Debashis, C. R. T. Young, 3D ESPI measurement of the strain fields introduced by strip-lining paintings, Proceedings of ICOM-CC Triennial Conference, 661 (2008).

34. M. Sutton, J.-J. Orteu, H. Schreier, Image correlation for shape, motion and deformation measurements, Springer, (2009).

35. D. Khennouf, J. M. Dulieu-Barton, A. R. Chambers, F. J. Lennard, and D. D. Eastop, Assessing the Feasibility of Monitoring Strain in Historical Tapestries Using Digital Image Correlation, Strain 46, 19-32 (2010).

36. J. M. Dulieu-Barton, D. Khennouf, A. R. Chambers, F. Lennard, and D. Eastop, Long term condition monitoring of tapestries using image correlation, Proceedings of the SEM Annual Conference, (2010).

37. M. Malesa, K. Malowany, L. Tymińska-Widmer, E. A. Kwiatkowska, M. Kujawińska, B. J. Rouba, Piotr Targowski, Application of Digital Image Correlation (DIC) for tracking deformations of canvas paintings, O3A: Optics for Arts, Architecture, and Archaeology III, edited by Luca Pezzati, Renzo Salimbeni, Proc. of SPIE Vol. 8084, 80840L (C) 2011 SPIE CCC code: 0277-786X/11/\$18 doi: $10.1117 / 12.889452$

38. J. M. Dulieu-Barton, L. Dokos, D. Eastop, F. Lennard, A. R. Chambers, M. Sahin, Deformation and strain measurment techniques for inspection of damage in works of art, Reviews in Conserwation, 6, 2005, s. 63-73.

39. D. Ambrosini, D. Paoletti, Holographic and speckle methods for the analysis of panel paintings. Developments since the early 1970s, Reviews in Conservation, 5, 2004, s. 38-48.

40. V. Tornari, A. Bonarou, V. Zafiropulos, C. Fotakis, N. Smyrnacis, Stssinopulos, Structural Evaluation of Restoration Processes with Holographic Diagnostic Inspection, Journal of Cultural Heritage, 4, 2003. s. 347-354.

41. V. Tornari, Optical and Digital HolographicInterferometry Applied in Art Conservation Structural Diagnosis, e-PRESERVATION Science, 3, 2006, s. 51-57.

42. Ł. Bratasz, K. Dzierżęga, A. Klisińska-Kopacz, R. Kozłowski, M. Łukomski, E. Peacock, A. Prokopowicz, J. Thomas, W. Zawadzki, Ochrona zabytkowych thanin. Projekt badawczy Mechanizmu Finansowego Europejskiego Obszaru Gospodarczego Bezpośrednie monitorowanie odksztatceń thanin w celu ochrony zabyt- 
kowych obiektón tekstylnych i podobrazi, dokument elektroniczny, tryb dostępu: http://www.muzeum.krakow.pl/uploads/media/Ochrona_zabytkowych_ tkanin_02.pdf

43. A. Guzowska, Pryygotowanie plócien dublażonych, pod kierunkiem prof. dr Bogumily Rouba w ZKMiRP UMK, Toruń 1996, nr arch. 183.

44. M. Gurba, Wykoraystanie metody tensometrii elektrooporowej $i$ optycznych metod rejestracii prąesuniéc do badania naprę̇én powstajacych w ptóciennych podtożach obrazón sz̧talugowych, pod kierunkiem prof. dr Bogumiły Rouba w ZKMiRP UMK, Toruń 2007, nr arch. 269.

45. P. Targowski, M. Góra, T. Bajraszewski, M. Szkulmowski, B. Rouba, T. ŁękawaWysłouch, L. Tymińska-Widmer, Optical Coherence Tomography for Tracking Canvas Deformation, Laser Chemistry, vol.2006, doi:10.1155/2006/93658, 8 pages, 2006.

46. T. Bajraszewski, I. Gorczyńska, B. Rouba, and P. Targowski, Spectral domain Optical Coherence Tomography as the Profilometric Tool for Examination of the Environmental Influence on Paintings on Canvas, in Lasers in the Conservation of Artworks, LACONA VI Proceedings, Vienna, Austria, Sept. 21-25, 2005, J. Nimmrichter, W. Kautek, and M. Schreiner, eds. (Springer Verlag, BerlinHeidelberg-New York, 2007), s. 507-512.

47. L. Tyminska-Widmer, P. Targowski, M. Góra, M. Iwanicka, T. Łękawa-Wysłouch, B. Rouba, Optical Coherence Tomography - a Novel Tool for the Examination of Oil Paintings, in Conservation Science 2007, Milan, 10-11 May 2007, Joyce Townsend et al., eds. (Archtype publishing, London, 2008), s. 175-182.

48. P. Targowski, B. J. Rouba, P. Karaszkiewicz, M. Iwanicka, L. Tymińska-Widmer, T. Łękawa-Wysłouch, E. A. Kwiatkowska, M. Sylwestrzak, Optyczna Koherentna Tomografia OCT - nowe narzedzie do dziatań konserwatorskich i inwentaryzacyjnych / Optical Coherence Tomography OCT - a novel tool for art conservation and cataloguing, Wiadomości konserwatorskie 26, 2009, s. 94-107.

49. P. Targowski, M. Iwanicka, L. Tymińska-Widmer, M. Sylwestrzak, E. A. Kwiatkowska, Structural Examination of Easel paintings with Oprical Coherence Tomography, Accounts of Chemical Research 43(6), 826-836 (2010).

50. Drexler W., Fujimoto J.G eds (2008), Optical Coherence Tomography, Technology and Applications. Berlin Heidelberg, Springer Verlag, 2008.

51. D. Stifter, Beyond biomedicine: a review of alternative applications and developments for optical coherence tomography. Applied Physics B: Lasers and Optics 88(3): 2007, s. 337-357.

52. P. Targowski, M. Iwanicka, Optical Coherence tomography for structural examination of cutural heritage objects and monitoring of restoration processes - a review, Applied Physics A, DOI: 10.1007/s00339-011-6687-3 


\section{Aneks: przykładowe tabele translacji}

Tabela 1. Translacja w próbkach podczas pierwszej fazy zwiększania wilgotności wyznaczona dla zmian $\mathrm{RH}$ od $50 \%$ do $70 \%$

\begin{tabular}{|c|c|c|c|c|c|}
\hline Nr próbki & Rodzaj płótna & Stężenie przeklejenia & Sposób przeklejenia & Konsolidant & Translacja w \\
\hline 33 & stare 4 & $15 \%$ & na zimno & brak & 93 \\
\hline 72 & stare6 & $15 \%$ & na ciepło & BEVA & 86 \\
\hline 72 & stare6 & $15 \%$ & na ciepło & BEVA & 85 \\
\hline 69 & stare2 & $15 \%$ & na ciepło & brak & 84 \\
\hline 1 & regularne & $5 \%$ & na zimno & brak & 81 \\
\hline 33 & stare4 & $15 \%$ & na zimno & brak & 81 \\
\hline 61 & regularne & $15 \%$ & na ciepło & brak & 79 \\
\hline 25 & regularne & $15 \%$ & na zimno & brak & 76 \\
\hline 37 & regularne & $5 \%$ & na ciepło & brak & 75 \\
\hline 45 & stare6 & $5 \%$ & na ciepło & brak & 75 \\
\hline 69 & stare2 & $15 \%$ & na ciepło & brak & 74 \\
\hline 29 & nieregularne & $15 \%$ & na zimno & brak & 71 \\
\hline 9 & stare1 & $5 \%$ & na zimno & brak & 70 \\
\hline 5 & nieregularne & $5 \%$ & na zimno & brak & 70 \\
\hline 65 & nieregularne & $15 \%$ & na ciepło & brak & 68 \\
\hline 65 & nieregularne & $15 \%$ & na ciepło & brak & 67 \\
\hline 29 & nieregularne & $15 \%$ & na zimno & brak & 62 \\
\hline 32 & nieregularne & $15 \%$ & na zimno & BEVA & 59 \\
\hline 26 & regularne & $15 \%$ & na zimno & PAW & 59 \\
\hline 32 & nieregularne & $15 \%$ & na zimno & BEVA & 57 \\
\hline 5 & nieregularne & $5 \%$ & na zimno & brak & 56 \\
\hline 40 & regularne & $5 \%$ & na ciepło & BEVA & 56 \\
\hline 9 & stare1 & $5 \%$ & na zimno & brak & 55 \\
\hline 41 & nieregularne & $5 \%$ & na ciepło & brak & 55 \\
\hline 1 & regularne & $5 \%$ & na zimno & brak & 53 \\
\hline 68 & nieregularne & $15 \%$ & na ciepło & BEVA & 53 \\
\hline 30 & nieregularne & $15 \%$ & na zimno & PAW & 52 \\
\hline 64 & regularne & $15 \%$ & na ciepło & BEVA & 49 \\
\hline 46 & stare2 & $5 \%$ & na ciepło & PAW & 48 \\
\hline 36 & stare2 & $15 \%$ & na zimno & BEVA & 47 \\
\hline
\end{tabular}


Teresa ŁęKAWA-WysŁouch, BogumiŁa J. RoubA

\begin{tabular}{|c|c|c|c|c|c|}
\hline Nr próbki & Rodzaj płótna & Stężenie przeklejenia & Sposób przeklejenia & Konsolidant & Translacja w \\
\hline 37 & regularne & $5 \%$ & na ciepło & brak & 46 \\
\hline 45 & stare6 & $5 \%$ & na ciepło & brak & 46 \\
\hline 42 & nieregularne & $5 \%$ & na ciepło & PAW & 46 \\
\hline 61 & regularne & $15 \%$ & na ciepło & brak & 44 \\
\hline 10 & stare2 & $5 \%$ & na zimno & PAW & 44 \\
\hline 34 & stare5 & $15 \%$ & na zimno & PAW & 43 \\
\hline 30 & nieregularne & $15 \%$ & na zimno & PAW & 41 \\
\hline 66 & nieregularne & $15 \%$ & na ciepło & PAW & 39 \\
\hline 12 & stare3 & $5 \%$ & na zimno & BEVA & 36 \\
\hline 28 & regularne & $15 \%$ & na zimno & BEVA & 36 \\
\hline 38 & regularne & $5 \%$ & na ciepło & PAW & 35 \\
\hline 33 & stare4 & $15 \%$ & na zimno & brak & 33 \\
\hline 62 & regularne & $15 \%$ & na ciepło & PAW & 33 \\
\hline 25 & regularne & $15 \%$ & na zimno & brak & 32 \\
\hline 6 & nieregularne & $5 \%$ & na zimno & PAW & 32 \\
\hline 12 & stare3 & $5 \%$ & na zimno & BEVA & 32 \\
\hline 36 & stare2 & $15 \%$ & na zimno & BEVA & 32 \\
\hline 8 & nieregularne & $5 \%$ & na zimno & BEVA & 31 \\
\hline 42 & nieregularne & $5 \%$ & na ciepło & PAW & 31 \\
\hline 66 & nieregularne & $15 \%$ & na ciepło & PAW & 31 \\
\hline 70 & stare8 & $15 \%$ & na ciepło & PAW & 30 \\
\hline 44 & nieregularne & $5 \%$ & na ciepło & BEVA & 30 \\
\hline 48 & stare7 & $5 \%$ & na ciepło & BEVA & 29 \\
\hline 26 & regularne & $15 \%$ & na zimno & PAW & 29 \\
\hline 8 & nieregularne & $5 \%$ & na zimno & BEVA & 28 \\
\hline 2 & regularne & $5 \%$ & na zimno & PAW & 28 \\
\hline 44 & nieregularne & $5 \%$ & na ciepło & BEVA & 28 \\
\hline 10 & stare2 & $5 \%$ & na zimno & PAW & 27 \\
\hline 40 & regularne & $5 \%$ & na ciepło & BEVA & 27 \\
\hline 33 & stare4 & $15 \%$ & na zimno & brak & 26 \\
\hline 41 & nieregularne & $5 \%$ & na ciepło & brak & 26 \\
\hline 70 & stare8 & $15 \%$ & na ciepło & PAW & 26 \\
\hline 62 & regularne & $15 \%$ & na ciepło & PAW & 23 \\
\hline 34 & stare5 & $15 \%$ & na zimno & PAW & 23 \\
\hline
\end{tabular}




\begin{tabular}{|c|c|c|c|c|c|}
\hline Nr próbki & Rodzaj płótna & Stężenie przeklejenia & Sposób przeklejenia & Konsolidant & Translacja w \\
\hline 6 & nieregularne & $5 \%$ & na zimno & PAW & 23 \\
\hline 48 & stare7 & $5 \%$ & na ciepło & BEVA & 23 \\
\hline 68 & nieregularne & $15 \%$ & na ciepło & BEVA & 22 \\
\hline 38 & regularne & $5 \%$ & na ciepło & PAW & 22 \\
\hline 2 & regularne & $5 \%$ & na zimno & PAW & 22 \\
\hline 64 & regularne & $15 \%$ & na ciepło & BEVA & 22 \\
\hline 46 & stare2 & $5 \%$ & na ciepło & PAW & 20 \\
\hline 28 & regularne & $15 \%$ & na zimno & BEVA & 12 \\
\hline 4 & regularne & $5 \%$ & na zimno & BEVA & 10 \\
\hline 4 & regularne & $5 \%$ & na zimno & BEVA & 9 \\
\hline
\end{tabular}

Tabela 2. Translacja w próbkach podczas pierwszej fazy zmniejszania wilgotności (przesuszania) wyznaczona dla zmian $\mathrm{RH}$ od $45 \%$ do $23 \%$

\begin{tabular}{|c|c|c|c|c|c|}
\hline Nr próbki & Rodzaj płótna & Stężenie przeklejenia & Sposób przeklejenia & Konsolidant & Translacja w \\
\hline 70 & stare8 & $15 \%$ & na ciepło & PAW & 192 \\
\hline 61 & regularne & $15 \%$ & na ciepło & brak & 165 \\
\hline 70 & stare8 & $15 \%$ & na ciepło & PAW & 130 \\
\hline 25 & regularne & $15 \%$ & na zimno & brak & 129 \\
\hline 61 & regularne & $15 \%$ & na ciepło & brak & 124 \\
\hline 66 & nieregularne & $15 \%$ & na ciepło & PAW & 123 \\
\hline 29 & nieregularne & $15 \%$ & na zimno & brak & 116 \\
\hline 62 & regularne & $15 \%$ & na ciepło & PAW & 116 \\
\hline 40 & regularne & $5 \%$ & na ciepło & BEVA & 106 \\
\hline 66 & nieregularne & $15 \%$ & na ciepło & PAW & 104 \\
\hline 40 & regularne & $5 \%$ & na ciepło & BEVA & 103 \\
\hline 29 & nieregularne & $15 \%$ & na zimno & brak & 96 \\
\hline 62 & regularne & $15 \%$ & na ciepło & PAW & 94 \\
\hline 25 & regularne & $15 \%$ & na zimno & brak & 92 \\
\hline 30 & nieregularne & $15 \%$ & na zimno & PAW & 89 \\
\hline 72 & stare6 & $15 \%$ & na ciepło & BEVA & 89 \\
\hline 38 & regularne & $5 \%$ & na ciepło & PAW & 87 \\
\hline 28 & regularne & $15 \%$ & na zimno & BEVA & 85 \\
\hline 28 & regularne & $15 \%$ & na zimno & BEVA & 83 \\
\hline 34 & stare 5 & $15 \%$ & na zimno & PAW & 79 \\
\hline
\end{tabular}




\begin{tabular}{|c|c|c|c|c|c|}
\hline Nr próbki & Rodzaj płótna & Stężenie przeklejenia & Sposób przeklejenia & Konsolidant & Translacja w \\
\hline 30 & nieregularne & $15 \%$ & na zimno & PAW & 73 \\
\hline 33 & stare4 & $15 \%$ & na zimno & brak & 71 \\
\hline 32 & nieregularne & $15 \%$ & na zimno & BEVA & 70 \\
\hline 34 & stare5 & $15 \%$ & na zimno & PAW & 69 \\
\hline 45 & stare6 & $5 \%$ & na ciepło & brak & 68 \\
\hline 12 & stare2 & $5 \%$ & na zimno & BEVA & 67 \\
\hline 64 & regularne & $15 \%$ & na ciepło & BEVA & 67 \\
\hline 38 & regularne & $5 \%$ & na ciepło & PAW & 66 \\
\hline 8 & nieregularne & $5 \%$ & na zimno & BEVA & 64 \\
\hline 69 & stare2 & $15 \%$ & na ciepło & brak & 63 \\
\hline 65 & nieregularne & $15 \%$ & na ciepło & brak & 63 \\
\hline 69 & stare2 & $15 \%$ & na ciepło & brak & 62 \\
\hline 37 & regularne & $5 \%$ & na ciepło & brak & 62 \\
\hline 64 & regularne & $15 \%$ & na ciepło & BEVA & 62 \\
\hline 37 & regularne & $5 \%$ & na ciepło & brak & 61 \\
\hline 8 & nieregularne & $5 \%$ & na zimno & BEVA & 60 \\
\hline 65 & nieregularne & $15 \%$ & na ciepło & brak & 59 \\
\hline 33 & stare4 & $15 \%$ & na zimno & brak & 58 \\
\hline 45 & stare6 & $5 \%$ & na ciepło & brak & 58 \\
\hline 68 & nieregularne & $15 \%$ & na ciepło & BEVA & 55 \\
\hline 9 & stare1 & $5 \%$ & na zimno & brak & 54 \\
\hline 10 & stare2 & $5 \%$ & na zimno & PAW & 54 \\
\hline 4 & regularne & $5 \%$ & na zimno & BEVA & 53 \\
\hline 32 & nieregularne & $15 \%$ & na zimno & BEVA & 53 \\
\hline 9 & stare1 & $5 \%$ & na zimno & brak & 52 \\
\hline 1 & regularne & $5 \%$ & na zimno & brak & 50 \\
\hline 12 & stare2 & $5 \%$ & na zimno & BEVA & 49 \\
\hline 1 & regularne & $5 \%$ & na zimno & brak & 47 \\
\hline 2 & regularne & $5 \%$ & na zimno & PAW & 47 \\
\hline 5 & nieregularne & $5 \%$ & na zimno & brak & 46 \\
\hline 26 & regularne & $15 \%$ & na zimno & PAW & 43 \\
\hline 10 & stare2 & $5 \%$ & na zimno & PAW & 42 \\
\hline 46 & stare2 & $5 \%$ & na ciepło & PAW & 42 \\
\hline 68 & nieregularne & $15 \%$ & na ciepło & BEVA & 38 \\
\hline 36 & stare2 & $15 \%$ & na zimno & BEVA & 38 \\
\hline 5 & nieregularne & $5 \%$ & na zimno & brak & 36 \\
\hline
\end{tabular}




\begin{tabular}{|c|c|c|c|c|c|}
\hline Nr próbki & Rodzaj płótna & Stężenie przeklejenia & Sposób przeklejenia & Konsolidant & Translacja w \\
\hline 6 & nieregularne & $5 \%$ & na zimno & PAW & 36 \\
\hline 72 & stare6 & $15 \%$ & na ciepło & BEVA & 35 \\
\hline 2 & regularne & $5 \%$ & na zimno & PAW & 35 \\
\hline 41 & nieregularne & $5 \%$ & na ciepło & brak & 33 \\
\hline 48 & stare7 & $5 \%$ & na ciepło & BEVA & 33 \\
\hline 4 & regularne & $5 \%$ & na zimno & BEVA & 33 \\
\hline 6 & nieregularne & $5 \%$ & na zimno & PAW & 32 \\
\hline 41 & nieregularne & $5 \%$ & na ciepło & brak & 32 \\
\hline 44 & nieregularne & $5 \%$ & na ciepło & BEVA & 32 \\
\hline 46 & stare2 & $5 \%$ & na ciepło & PAW & 32 \\
\hline 36 & stare2 & $15 \%$ & na zimno & BEVA & 29 \\
\hline 48 & stare7 & $5 \%$ & na ciepło & BEVA & 27 \\
\hline 44 & nieregularne & $5 \%$ & na ciepło & BEVA & 26 \\
\hline 26 & regularne & $15 \%$ & na zimno & PAW & 25 \\
\hline 42 & nieregularne & $5 \%$ & na ciepło & PAW & 23 \\
\hline 42 & nieregularne & $5 \%$ & na ciepło & PAW & 16 \\
\hline
\end{tabular}

\section{Summary}

\section{An evaluation of the influence of the environmental changes on canvas supports of paintings}

The paper presents preliminary results of testing of paintings on canvas response to environmental fluctuations. The reasearch was made on the model paintings varying in the type of canvas support used, gelatine size and additional consolidated size. Optical Coherence Tomography (OCT) was used in particular application - where even semi-transparency of layers of invastigation object is not required - as a profilomeric tool for monitoring the response of the painting surface to climatic changes. The tested samples, strained on metal stretcher with force sensors, were examined insite climatic chamber, in conditions designed according to climate parameters usually experienced in sacral interiors and museums. During a few hours long cycle of moistering and drying, the displacement of a chosen point on the surface was monitored and recovered simultaneously in three dimensions $(\mathrm{X}, \mathrm{Y}, \mathrm{Z})$, with micrometer precision, and the data were recorded at the hard drive. The findings of tests indicate the relation between the technological aspects of paintings on canvas and their reaction to periodical climatic changes. 


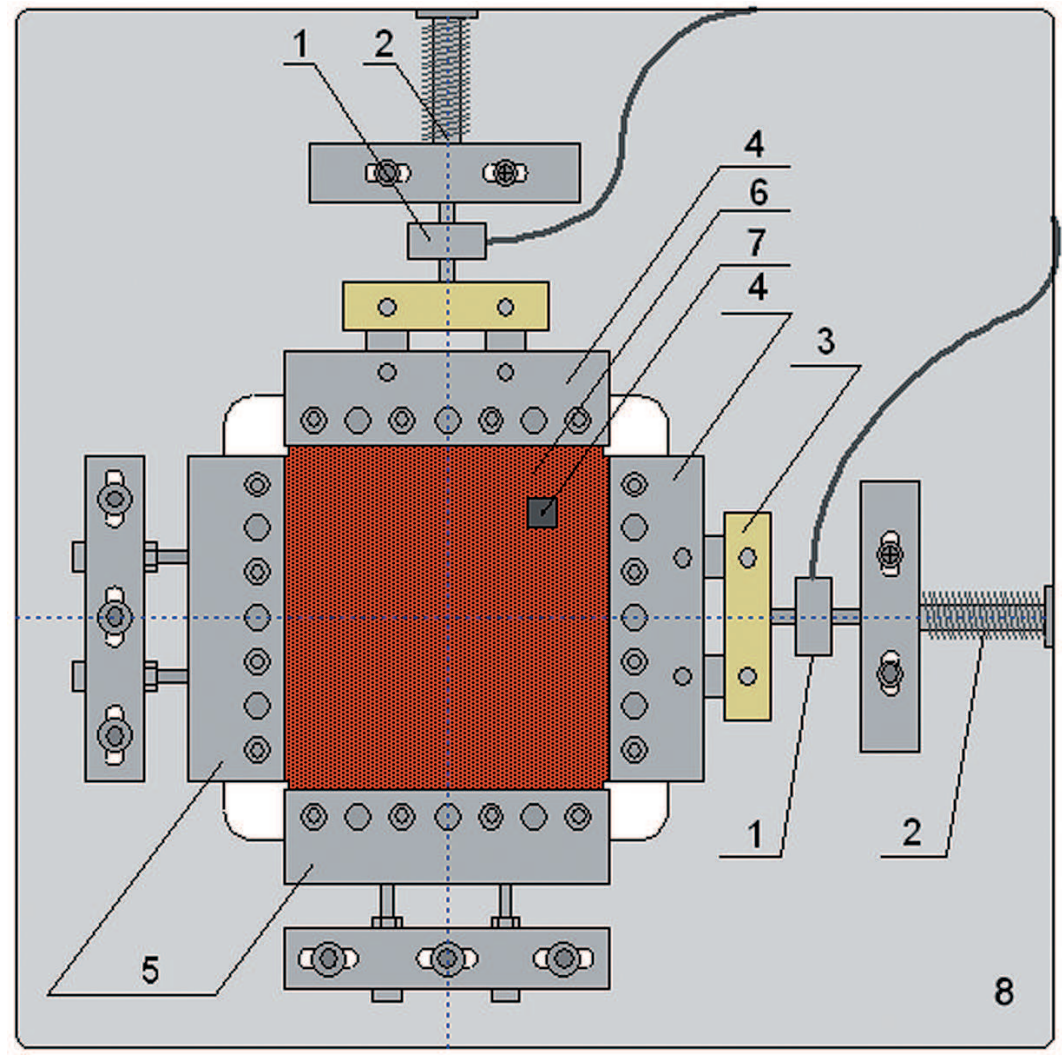

Il. 1. Schemat stanowiska do monitorowania wpływu zmian klimatycznych na malowidła na płótnie: (1) dwa tensometry mierzące naprężenia w kierunku wątku i osnowy próbek, (2) pokrętła dociskowe zaopatrzone w sprężyny, (3) ruchomy przegub pomiędzy tensometrem a luźną szczęką krosien, (4) ruchome szczęki krosien, (5) nieruchome szczęki krosien, (6) model badawczy imitujący obraz zamocowany w szczękach krosien, (7) punkt pomiarowy na powierzchni warstwy malarskiej - srebrzysta kropka na czarnym podkładzie, (8) płyta główna stanowiska 


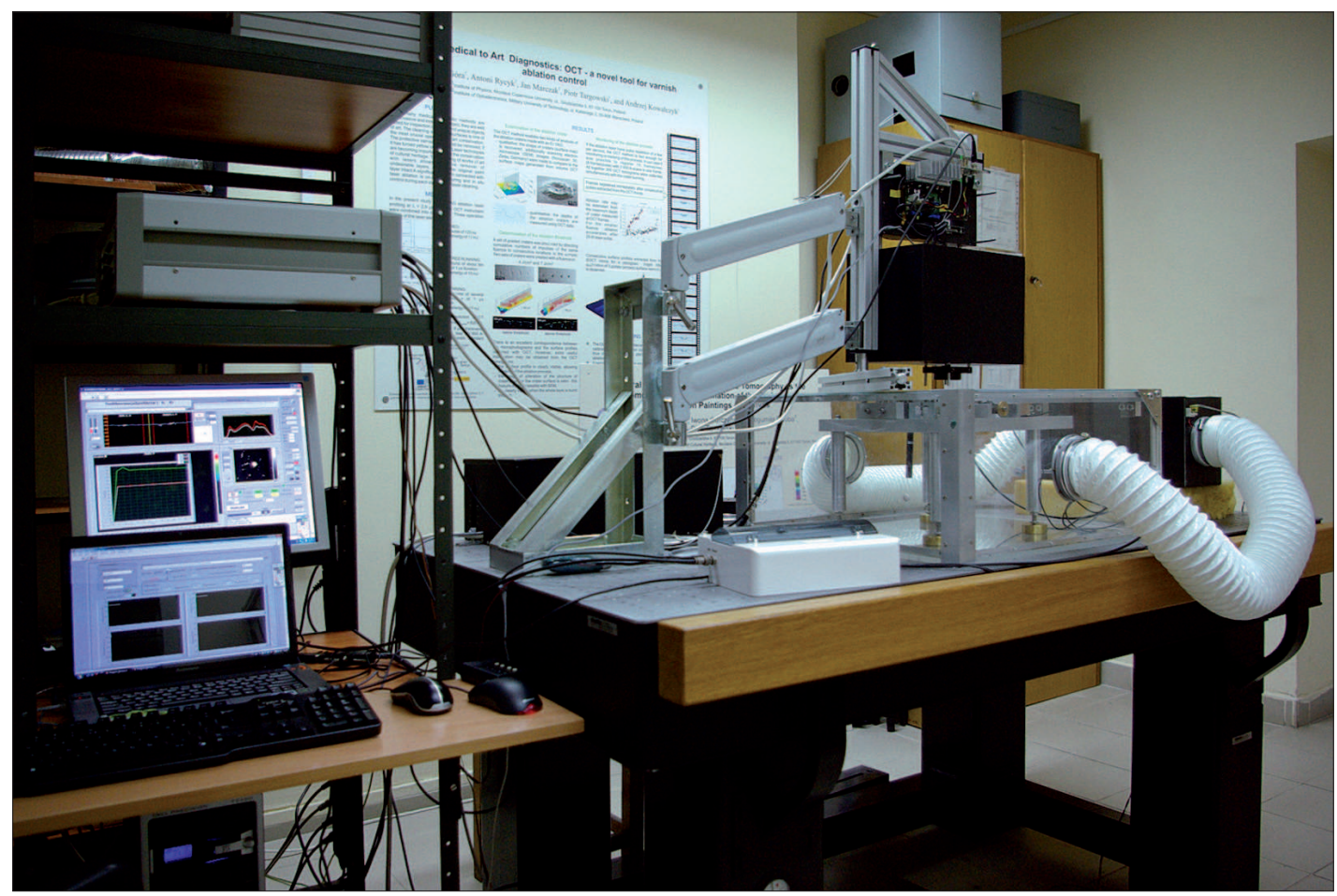

Il. 2. Układ pomiarowy OCT: głowica na wysięgniku nad komorą klimatyczną umiejscowioną na stole optycznym. Komora mieści wewnątrz stanowisko do monitorowania zmian w malowidłach na płótnie pod wpływem zmian klimatycznych w otoczeniu. Elastyczne rury z tworzywa transportuja parę wodną z mniejszej komory - magazynu wilgoci. Po lewej stanowisko komputerowe, gdzie w trakcie trwania eksperymentu zapisywane są dane 

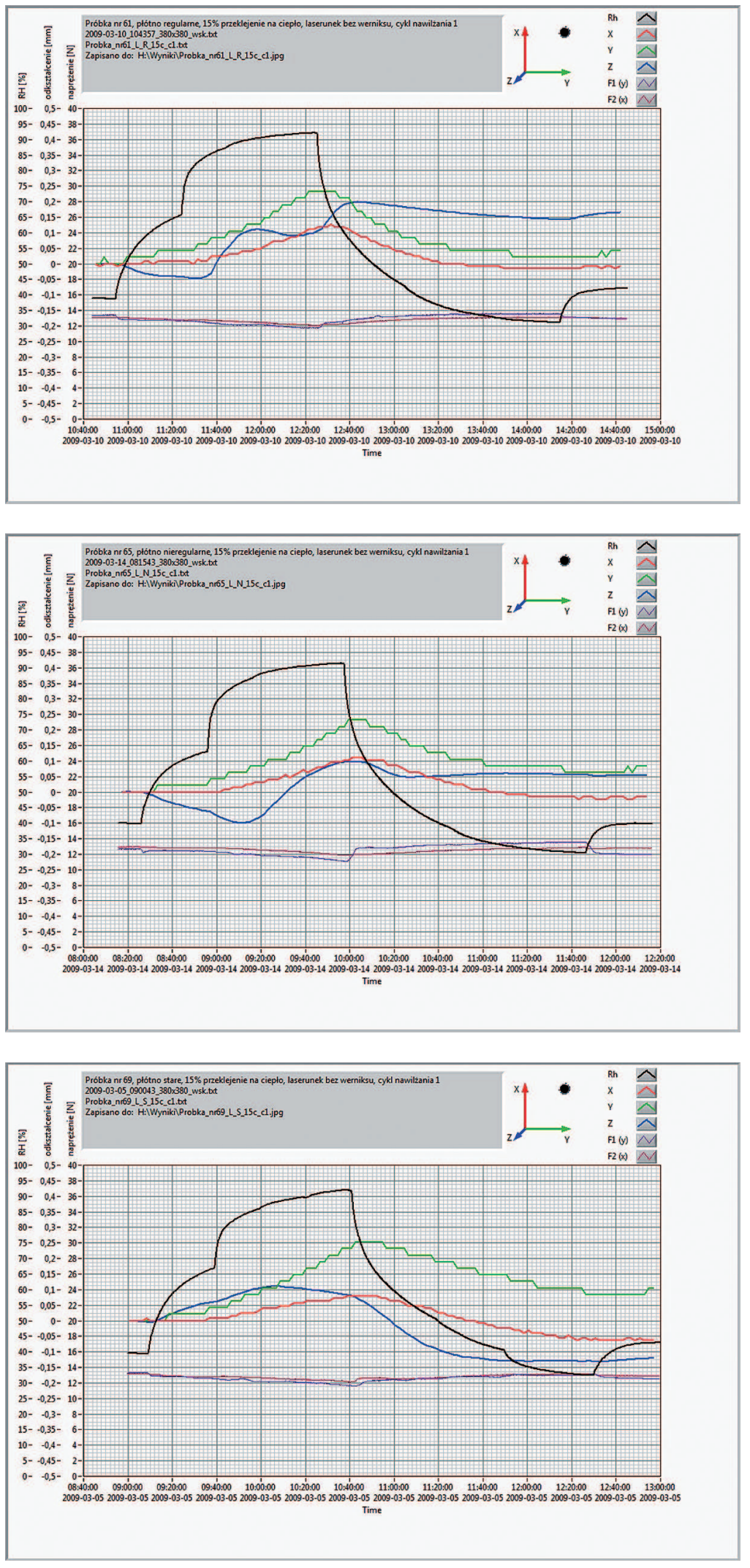

Il. 3. Przykładowe zestawienie wykresów dla pierwszego cyklu nawilżania modeli na różnych płótnach przeklejonych 15\% żelatyną techniczna aplikowana na ciepło i nie konsolidowanych dodatkowo innym spoi wem. Od góry: na płótnie regularnym, pośrodku na nieregularnym, na dole na starym płótnie 

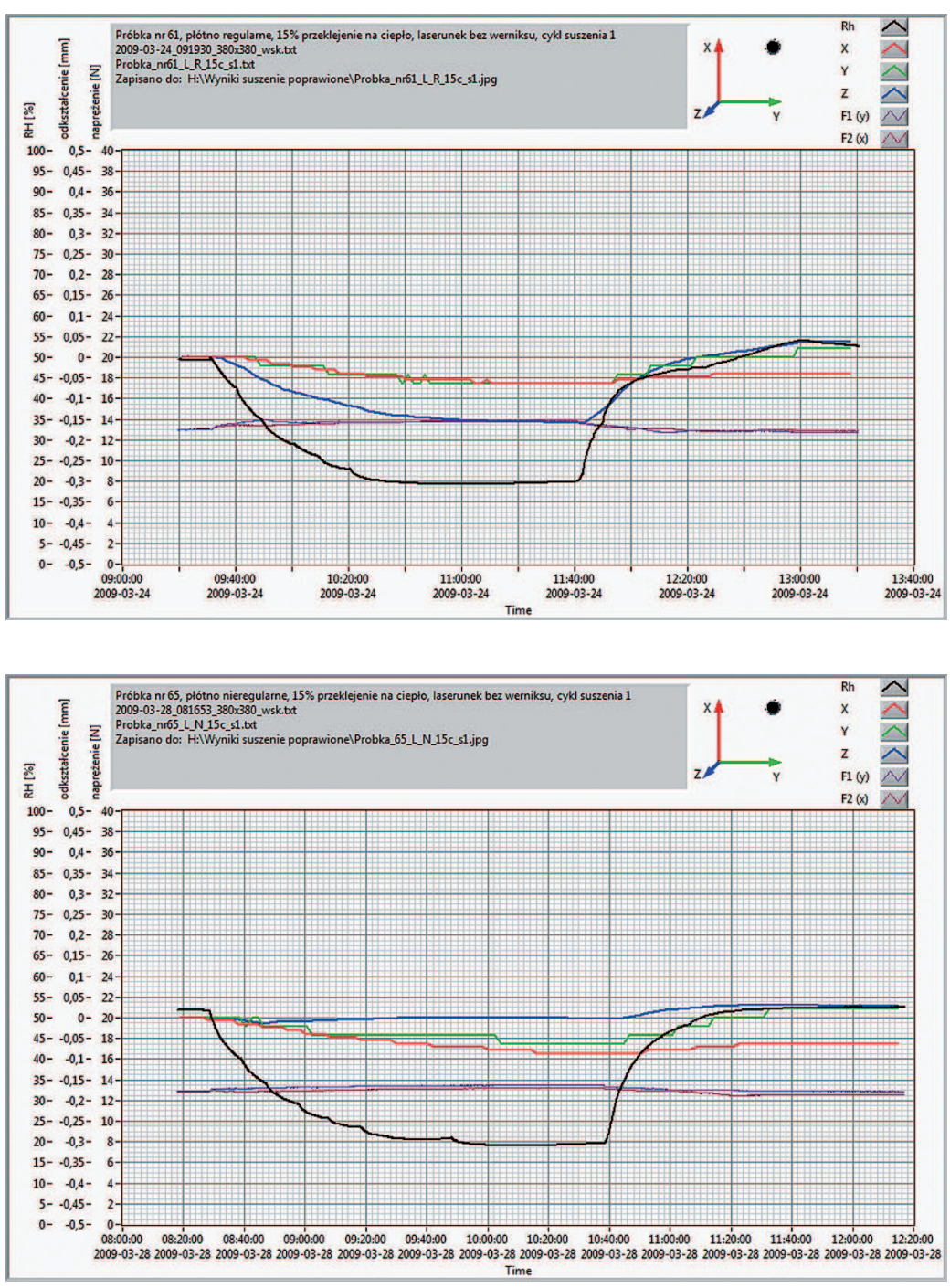

Il. 4. Przykładowe zestawienie wykresów dla pierwszego cyklu przesuszania próbek na różnych płótnach, przeklejonych $15 \%$ żelatyną techniczna aplikowana na ciepło (analogicznie do próbek z il. 3). Od góry: na płótnie regularnym, pośrodku na nieregularnym, na dole na płótnie starym

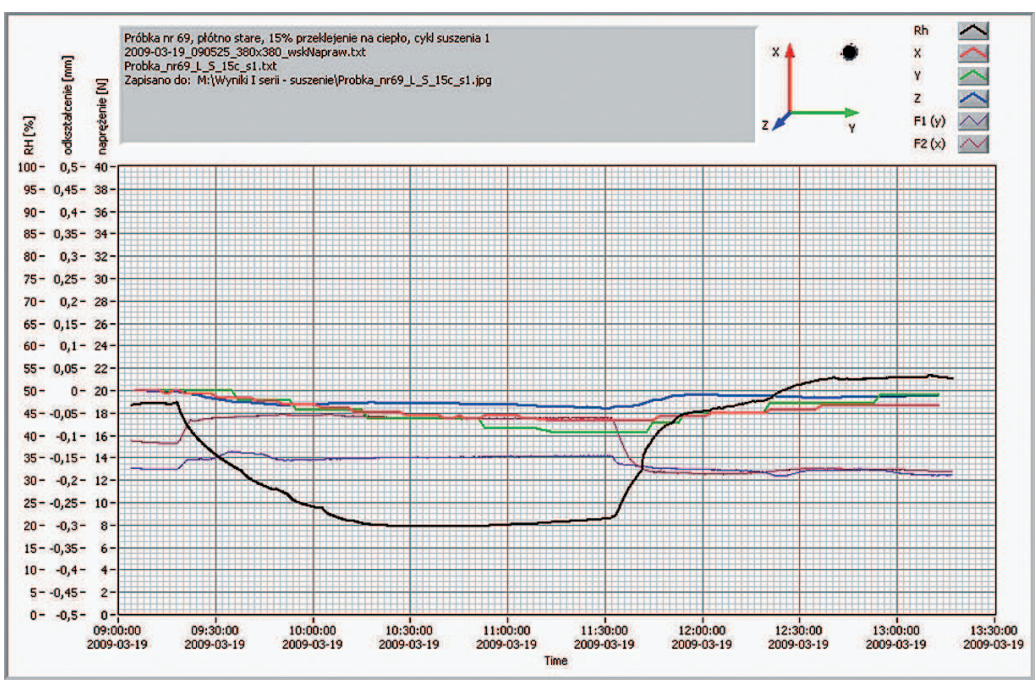


Próbki nr 61, 65, 69 - zestawienie współrzędnych Z. Przesuszanie - cykl pierwszy Trzy różne płótna: regularne, nieregularne i stare, jednakowe przeklejenia $15 \%$ na ciepło, bez konsolidacji
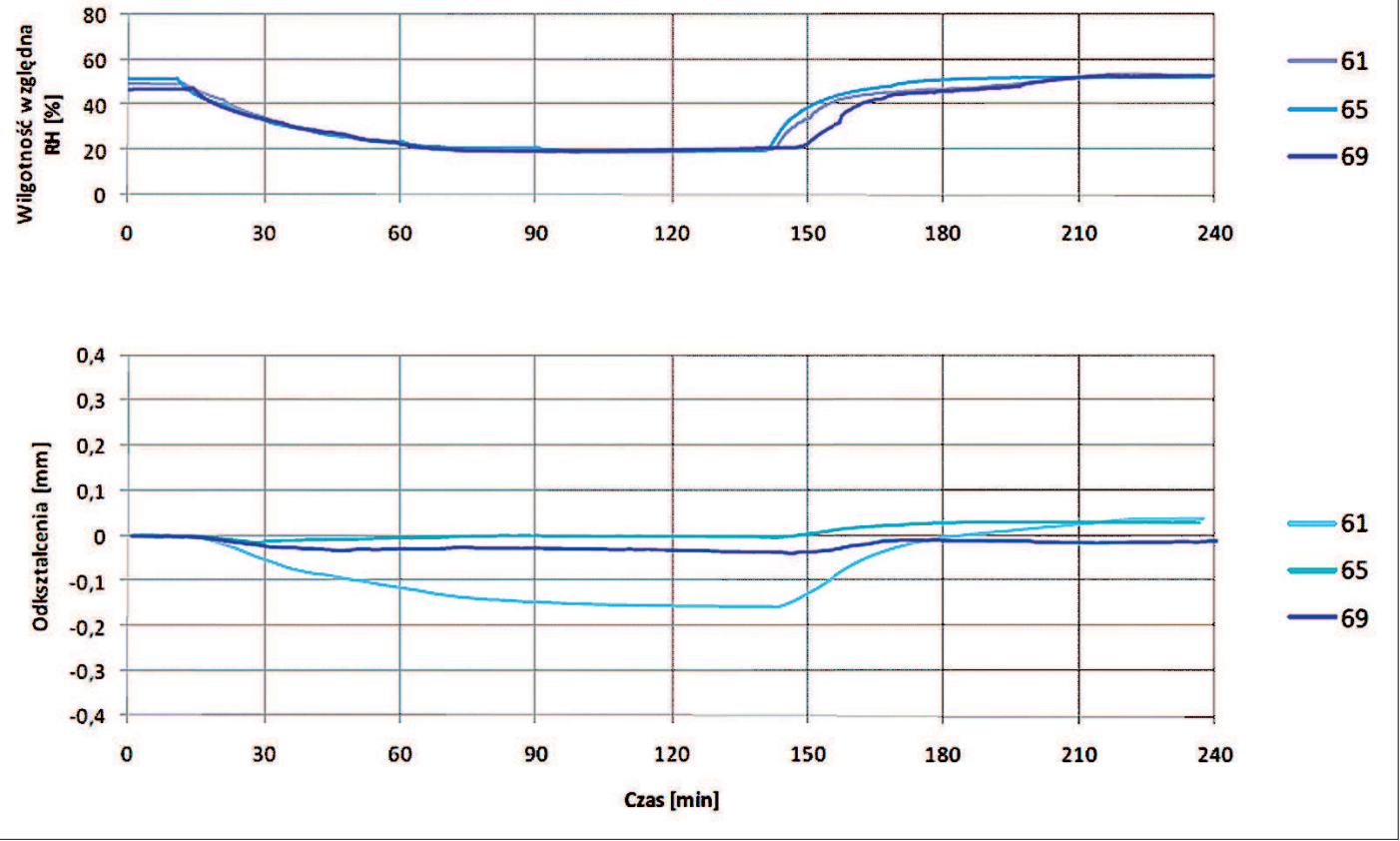

Il. 5. Przykładowe zestawienie wykresów dla pierwszego cyklu przesuszania próbek na różnych płótnach, przeklejonych 15\% żelatyną techniczną na ciepło (analogicznie do próbek z il. 4). Od góry porównanie zmian wilgotności względnej i odkształcenia w kierunku Z: na płótnie regularnym (próbka 61), nieregularnym (próbka 65), płótnie starym (próbka 69) 